\title{
Welfare of farmed insects
}

\author{
A. van Huis
}

Laboratory of Entomology, Wageningen University E Research, Droevendaalsesteeg 1, 6708 PB Wageningen, the Netherlands; arnold.vanhuis@wur.nl

Received: 23 June 2020 / Accepted: 21 September 2020

(c) 2020 Wageningen Academic Publishers

OPEN ACCESS CP) (1) REVIEW ARTICLE

\begin{abstract}
The recent interest in using insects as food and feed is based on their capacity to be a sustainable alternative to other protein sources. When farmed as mini livestock, the question is raised as to whether they are 'sentient beings' (selfconscious)? In researching this topic, the problem is that humans often expect animals to have the same subjective experience as we do (anthropomorphic) and consider themselves as the centre of the universe (anthropocentric). We discuss insects' sentience by looking at their brain, behaviour, and communicative abilities. The miniature brains of insects seem to be arranged in a very efficient functional way due to their very long evolutionary history. As for their behaviour, insects are capable of social and associative learning. Even dopamine, a neurotransmitter involved in reward and pleasure, plays a role. Human communication is mainly verbal, while for insects other means of information exchange are more important, such as tactile, chemical, visual, and vibrational. The distinction needs to be made between nociception and pain, the latter being an emotional experience. It is difficult to prove that insects can experience pain, although they have a large repertoire of withdrawal and defensive behavioural responses. The philosophical attitudes deal with how we view insects and their relations to humans. This also determines the ethical attitude and how we should treat them. Are they just there for our benefit or do we consider them as co-animals? Insects as food requires that many insects must be killed. However, the number killed may not be different when one chooses a plant-based diet. It is concluded that insects should be farmed and killed using the precautionary principle, which assumes that they can experience pain. To discuss the consequences for the industry sector that produces insects for food and feed, we used Brambell's five freedoms as a framework.
\end{abstract}

Keywords: edible insects, ethics, invertebrate welfare, nociception, pain

\section{Introduction}

Although most animal species on earth are insects (Mora et al., 2011; Stork, 2018), welfare issues related to invertebrates have not received a lot of attention. This oversight has to do with assumptions that invertebrates do not experience pain and stress, reinforced by the public's negative view of invertebrates (Horvath et al., 2013).

For more than four millennials insects have been domesticated, notably the silkworm and the bee. Insects are now also reared for a number of other purposes (Boppré and Vane-Wright, 2019): research, pollination, insect pest and weed management such as biological control and sterile insect technique, recreation and entertainment, medicine (e.g. maggot therapy) and as food for humans and feed for animals. In many tropical countries, insects have been harvested for food for centuries. However, it is only in the last ten years that the interest in using insects as food for humans and feed for animals has increased exponentially (Van Huis, 2020). This is because insects are increasingly being considered as a high-quality, efficient, and sustainable alternative protein source for both the food and feed sector. This means that billions of insects are and will be farmed, often in industrial settings.

Public concerns about the current livestock industry focusses on the conditions in which livestock are reared, transported, and slaughtered. For insects farmed as minilivestock similar concerns are being expressed. This has a lot to do with the question of whether insects are considered 'sentient beings' (beings with consciousness). Therefore, 
welfare issues need to be addressed. For example: what are the requirements of rearing specific insects, what about their health, and how can they be killed 'humanely'? (PaliSchöll et al., 2018).

There is also a discussion on how to manage insect welfare in experimental research. However, we will not deal with this here but instead refer the reader to publications on this topic (Drinkwater et al., 2019; Moltschaniwskyj et al., 2007; Pollo and Vitale, 2019; Wilson-Sanders, 2011).

The problem when discussing the question of whether insects have feelings, is that insects are viewed in an anthropomorphic manner. We expect animals to have the same subjective experiences as a human. Words often used in this context are consciousness and sentience. For that reason, we wish to define those words. Consciousness has been defined as 'the quality or state of being aware of an external object or something within oneself' ${ }^{\prime}$ while sentient has been defined as 'responsive to or conscious of sense impressions'. Consciousness, or simply the presence of subjective experience, can be studied in humans in three different ways: neurological, behavioural and verbal (Barron and Klein, 2016). Each of these topics will be discussed for invertebrates below. We will then discuss whether insects would be able to experience pain, before embarking on some philosophical theories. Based on the earlier deliberations, we are faced with the ethical issue of how to deal with insects. Lastly, we will discuss how the insect food and feed industry should deal with insect welfare.

\section{Neurological arguments}

Invertebrates have an evolutionary history of 500 million years, while humans (Homo spp.) have a history of 2.5 million years. Conscious processes have probably arisen independently on many occasions during the evolution of vertebrates and invertebrates (Le Neindre et al., 2017: 119). According to Budelmann (1995) the nervous system of cephalopods and insects has the highest degree of centralisation ('cerebralisation') for any invertebrate. This considerably reduces the time for information processing between stimulus reception and behavioural reactions. Barron and Klein (2016) and Klein and Barron (2016) contend that the integrative functional arrangements in the insect brain have many parallels with that of the vertebrate midbrain and the insect brain is thus capable of the same neural modelling, and hence of conscious experience. The question is whether neuron numbers by themselves are critical for the neural implementation of sentience. There is the a priori and maybe erroneous assumption that small brains are unlikely to support cognition or sentience

\footnotetext{
${ }^{1}$ https://www.merriam-webster.com/dictionary/ consciousness? src =search-dict-box.
}

(Mikhalevich and Powell, 2020). The number of neurons in the brain of the bee, considered to have an impressive behavioural repertoire, is 960,000 (Menzel and Giurfa, 2001), compared to 75 million for a mouse (HerculanoHouzel et al., 2006) and 85 billion (Herculano-Houzel, 2009) for a human. The estimated number of neurons in the brains of a mealworm was estimated to be only 25,000 (Scherer et al., 2017). However, if sentience is a function of structural arrangements of neural operations, neuron numbers may not be the most important criterion. Sentience may then be present in brains of different sizes. The mechanism of sentience even in large brains may require more than a subset, even a small subset, of available neurons (Merker, 2016). The miniature brains of insects exhibit a sophisticated behavioural repertoire and cognitive capabilities often go beyond simple associative learning (Giurfa, 2013). Andrews (2011) mentions how difficult it is to identify functionally analogous pathways in invertebrates with fundamentally differently organised central nervous systems such as in vertebrates. Tomasik (2019) even wonders whether smaller animals have faster subjective experiences than larger ones, considering their greater temporal resolution of vision. Would a higher brain metabolic rate (neuronal firing being one component) relate to moral weight of the mind?

\section{Behavioural arguments}

In a 1986 review by Carew and Sahley (1986) on invertebrate learning and memory, the belief was stated that the distinction between vertebrate and invertebrate learning and memory will diminish as our understanding of underlying mechanisms increases. Social learning (acquiring new behaviours by observing and imitating others) may not be restricted to large-brained animals, which are often assumed to possess superior cognitive abilities. Insects are capable of social learning (Coolen et al., 2005): take the example of wood crickets (Nemobius sylvestris) using congeners' behaviour by hiding under leaves to avoid wolf spiders (Pardosa spp.). Associate learning has also been demonstrated in different insect groups such as honeybees (Leadbeater and Chittka, 2007), ants and moths (Giurfa, 2013). Many experiments have been done with associative olfactory and visual learning in the fruit fly Drosophila melanogaster (Guo and Guo, 2005), and how dopamine is involved (Karam et al., 2019). In humans the neurotransmitter dopamine is involved in motivational processes as well as reward, pleasure and addiction. Perry et al. (2016) demonstrated that bumblebees' behaviour is influenced by dopamine. Bees learned to fly quickly to one colour/cylinder location to obtain sucrose and slowly to a different colour/cylinder location that contained only water. When bees were induced with a positive affective state (giving them an unexpected 60\% sucrose reward) they flew faster to a cylinder with ambiguous cues than non-rewarded bees. These behavioural changes disappeared with topical 
application of the dopamine antagonist fluphenazine. It has also been shown that bees are able to distinguish between human painting styles or to recognise faces (Mikhalevich and Powell, 2020).

However, whether 'emotion-like' states in insects are accompanied by emotional feelings is a question that remains unanswered (Mendl et al., 2011; Mendl and Paul, 2016). Also, according to Mason (2011), the problem-solving and stimulus-recognition skills of invertebrates, and their cognitive abilities like responses to tissue-damaging stimuli and escape mechanisms, are no evidence for conscious affective states and the ability to suffer. Otherwise, he states, we should be worrying about the well-being of computers.

In mobile, spatially-orienting animals there should be a central convergent interface for behavioural decisionmaking for target and action selection, and motivational ranking, and there is often a delay between target selection and goal acquisition (Merker, 2016; Paul and Mendl, 2016). Barron and Klein (2016) mention examples of how insects process topographically organised visual information. For example, Tarsitano (2006) showed that the jumping spider, Portia labiate, can make complete detours in which it moves away from a goal (i.e. prey) before approaching it. Decisionmaking occurred gradually, during both the scanning and the locomotory phases in the form of vicarious trial and error attempts.

Giurfa (2013) issues a warning about experimental designs to study insect behaviour in which the restricted animal can only do what the experimenter allows it to do.

\section{Verbal arguments}

The effectiveness of human communication is often mentioned as evidence of humans being the most unique and highly-evolved animals. It is commonly assumed that there is no equivalent to human language in other animal species. Identifying meaning in non-human animal communication is probably the most difficult task in linguistics because of our limited ability to infer the real goals and intentions of non-human animals (Prat, 2019). One problem with effective communication is that tests are conducted in the expectation that animals will perform in a similar way to humans (Lockwood, 1987). In animal tests dealing with auditory communication, Prat (2019) considered it bothersome that humans in tests are assumed to be unique and superior, while studies of nonhuman animals' vocal communication provided results like those expected if similar methods were to be applied to human vocal behaviour. Human communication centres on vocal and visual means. However, insects not only have these communication means, but also use other means of exchanging information more than humans do, e.g. tactile, chemical (smell and taste), and vibrational (Hedwig, 2014; Roitberg, 2018; Yack, 2016).

\section{Can insects experience pain?}

In invertebrates the discussion centres on the difference between pain and nociception. The definition of pain according to the International Association for the Study of Pain is 'an unpleasant sensory and emotional experience associated with actual or potential tissue damage', while nociception has been defined as 'the ability to detect stimuli that elicit damage to the body or the potential for such damage, the difference being 'pain has both an emotional and a sensory component, and this latter component, nociception, refers specifically to the detection of damaging or potentially damaging stimuli' (Burrell, 2017). These nociceptive signals in vertebrates are processed by the central nervous system and perceived as pain. Some authors believe that insects cannot experience pain. Eisemann et al. (1984) was one of the first who embarked on the question and concluded that 'the evidence from consideration of the adaptive role of pain, the neural organisation of insects and observations of their behaviour does not appear to support the occurrence in insects of a pain state, such as occurs in humans.' They conducted an oft-cited experiment in which a locust continued to feed while itself being eaten by a mantis. However, Sherwin (2001) was not impressed because vertebrate prey species may also have a selective advantage in not showing pain or injury to a predator. Nociception often causes a withdrawal response, and a number of examples can be given such as the defensive responses of Manduca sexta larvae as a response to noxious stimuli (Walters et al., 2001) or the directional rolling of Drosophila larvae to escape the attack of the parasitoid wasp Leptopilina boulardi (Hwang et al., 2007), noxious heat or harsh mechanical stimulation (Im and Galko, 2012; Tracey et al., 2003).

Bateson (1991) points to the fact that the less animals are like humans, the more difficult it is to assess pain in them. According to Elwood (2011) the rapid learning to avoid pain, coupled with a prolonged memory, seem to indicate that central processing is involved rather than simple reflexes. According to this author, invertebrates are capable of using complex information, suggesting a cognitive ability to have a fitness benefit from a pain experience. Although evidence is not conclusive, this seems to indicate that there is more than just nociception. Sneddon et al. (2014) have put forward an interesting idea: the principle of triangulation. They argue that when the neurological, behavioural, and verbal arguments are taken in isolation, it cannot be considered as definitive evidence of 'pain' in animals, but when using a multimodal approach it may well be. 


\section{Philosophical theories}

Human empathy for insects in general is low, maybe because 'invertebrates look far less like us' (Smyth, 1978). Another reason could be that in Western cultures insects are considered dirty, disgusting, and dangerous (Looy et al., 2014) and this negative attitude is reflected in idioms, proverbs, and slogans about insects (Meyer-Rochow and Kejonen, 2020). Mikhalevich and Powell (2020) also believe that the moral exclusion of invertebrates is caused by the distorting influence of the empathy gap and disgust response. In general, in the animal kingdom invertebrates are considered at the 'lower end' and humans at the extreme 'upper end' (Andrews, 2011). This is reinforced by the reputation of some insect species, like malaria mosquitoes or the desert locust, which can have a dramatic negative influence on human well-being. Others, such as houseflies, are considered a nuisance. The threat of insects to human welfare has already been mentioned in very early articles (Gossard, 1909).

The importance of insects has only been highlighted very recently because of the decline of insect biomass in protected areas of Europe (Hallmann et al., 2017) and other parts of the world (Van Klink et al., 2020). This has drawn attention to the importance of the ecological services that insects provide, such as pollination. Crop production to the value of 235-577 billion US\$ is at risk because of pollinator loss (IPBES, 2019). Natural biological control by predators, parasitoids and entomopathogens of crop pests provides a value of 400 billion US\$ per year (Costanza et $a l ., 1997)$. In addition, there are other services relating to provisioning (e.g. insects as nutrients), supporting (e.g. recycling) and cultural (e.g. recreation and bio-indicators). We humans may have to be a bit more modest given that Homo sapiens have only been around for half a million years, while insects have a history of 400 million years. There are about 5.5 million species of insects, of which one million have been described (Stork, 2018). Insects are very successful because of their design and processes (Van Huis, 2014). The American entomologist Edward O. Wilson indicated '... we need invertebrates, but they don't need us' and '... if invertebrates were to disappear, I doubt that the human species could last more than a few months' (Wilson, 1987). Considering the importance of insects in our ecosystem, they deserve our respect.

Homo sapiens and the fruit fly D. melanogaster had a common ancestor approximately 783 million years ago. A total of $15 \%$ of human genes and $46 \%$ of fly genes have orthologs (genes in different species that descended from the same ancestral sequence) to one or more fly and human genes, respectively (Shih et al., 2015). Insights gained from model genetic systems such as $D$. melanogaster can be applied immediately to vertebrate systems, by for instance analysing the function of human disease genes
(Bier, 2005). Many of the genetic pathways that guide basic developmental processes in vertebrates and invertebrates have remained largely intact during evolution.

According to Lestel and Taylor (2013), Westerners have lived in a culture that has constantly insisted on the man/ animal opposition. According to these authors, 'It is wrong to say that we live with animals; it is more correct to say that we are animals and animals are us. They quote Dominique Lestel: 'each species that disappears is a part of our imagination that we amputate perhaps irreversibly'. In their view, the major challenge is 'how we might consider the specificity of the human in proximity to other living beings (including plants and fungi) rather than setting strict boundaries.'

This brings us to the philosophical attitudes towards invertebrates. Mather (2011) mentions three: contractarian (animals are very different from humans; they are just machines and can be used for human benefit); utilitarian (looking at gains versus losses, e.g. bees should be protected as they assure pollination); and the rights-based approach (experiences and awareness of animals should be taken into account). Here comes the difference between animal welfare and animal rights. In animal welfare, animals have interests, but these can be traded away when human benefits justify that sacrifice if 'humane' guidelines are followed. In animal rights these interests cannot be sacrificed or traded away just because it might benefit others. Jena (2017) writes that in the animal welfare concept animals are provided with some comfort and freedom of movement in the period prior to being killed. However, there is no concern for the rights of animals; nor is there an interest in keeping the animals alive. For her, mere 'freedom', as formulated by Brambell (1965), is not sufficient and she opts for combining animal welfare and rights if the aim is to ensure their actual welfare.

Do insects have intrinsic value? This refers to an integrity that is independent of the animal's utility or use to humans (RDA, 2018). The consequence is that all instances of keeping and using animals must be justified in a manner that takes the animals' interests into account. In the Netherlands invertebrates fall under the Animals $\mathrm{Act}^{2}$ as soon as they are farmed for production purposes. This means that the government formally acknowledges their intrinsic value, thereby imposing clear welfare requirements (Section 1.3.2 and 1.3.3), such as the five freedoms of Brambell (1965): freedom from hunger and thirst, from discomfort, from pain, injury or disease, from fear and distress, and freedom to express normal behaviour.

\footnotetext{
${ }^{2}$ https://wetten.overheid.nl/jci1.3:c:BWBR0030250\&z=2013-01$01 \& g=2013-01-01$.
} 


\section{Ethics}

Ethics, also called moral philosophy, deals with concepts such as good and evil, and right and wrong. Therefore, the term 'food ethics' have been coined, which deals with animal welfare, the environment, health and fair trade (Barnhill and Doggett, 2018; McEachern, 2018; Nordgren, 2012). The consumption of animal products is rapidly growing in many developing countries because of increasing populations, urbanisation, and wealth. However, the livestock industry is considered an inefficient way of producing calories and nutrients (Alexander et al., 2017) and is associated with environmental, welfare, and health problems (McClements, 2019). So, what about alternative more sustainable protein sources, such as insects?

Some people have moral objections to insect consumption. This may have to do with the uncertainty as to whether insects are 'sentient beings' or with the very large number of insects that have to be killed compared to, for example a pig, making it unethical (Knutsson, 2016; Scherer et al., 2017). Therefore, plant-based diets may be preferred, although billions of insects need to be killed in order to allow for plant-based diets (Fischer, 2016, 2019).

There is also a question as to whether invertebrates or insects are taken as a group or whether we should have a species-specific approach considering the emotional and cognitive abilities and specific behavioural needs of certain insects (Gjerris et al., 2015; Mather and Carere, 2019). This may influence informed decisions regarding insect welfare and the ability of legislators to formulate accurate regulations. Also, Schukraft (2020) discusses whether there are degrees in the moral status of animals: e.g. are there differences in self-awareness, intelligence, autonomy, communicative ability, creativity, sociability, etc? This would particularly apply to insects with an enormous diversity (even between larvae and adults) and probably differ in moral status and capacity for welfare. Just consider the number of neurons in mealworms $(30,000)$ compared to a cockroach or bee (about one million).

When it comes to eating insects, Waltner-Toews and Houle (2017) indicate the complexity of the problem. On the one hand, they indicate that we do not want to cause pain or suffering to an animal in our care. On the other hand we are often unable to avoid causing their death: stepping on them when walking outside, eating fruits and vegetables that could have kept them alive, or eating them directly or inadvertently.

For economic reasons insect companies will try to put the insects in optimal conditions to obtain the highest production possible. So, normally, insect welfare is guaranteed. Increased insect welfare and economics can go together as shown by Adámková et al. (2017) when rearing mealworms: (1) death by freezing, compared to boiling, was found to be better from both a welfare and a nutritional perspective; and (2) nutritional deprivation affected 'welfare', but also negatively influenced the nutritional value and economics.

The ethical proposal put forward by Lockwood (1987) is that 'we ought to refrain from actions which may be reasonably expected to kill or cause nontrivial pain in insects when avoiding these actions has no, or only trivial, costs to our own welfare.'

\section{Farmed invertebrates}

\section{Justification}

There are insects that are harvested from nature, which is a traditional way of collecting food. What about when insects are reared for use as food or feed? This was practised in the Western world mainly to provide feed for reptiles, zoos, etc. However, over the last ten years there has been a steep rise in the number of companies that rear insects to produce food for humans and feed for animals. As discussed in food ethics, this is partly to do with all the problems associated with the current livestock production, which is not considered sustainable. Insect production is more sustainable than the production of beef, pork and poultry (Smetana, 2020; Smetana et al., 2015; Tapanen, 2018; Van Huis, 2019; Van Huis and Oonincx, 2017). Furthermore, insects can contribute to a circular economy because certain insect species can be reared on organic side streams (Bortolini et al., 2020; Cappellozza et al., 2019; Heckmann et al., 2019; Nava et al., 2020); this is important, considering that one third of our food and agricultural produce is wasted (FAO, 2014).

\section{Precautionary principle}

Then there is the question of how to deal with insects from an animal welfare' perspective. Some vegetarians may eat insects if insect welfare is guaranteed. However, when an animal rights approach is used, people may refrain from consuming them. But how are we to deal with the uncertainty that insects may experience pain? There are indications that insects experience pain but extensive scientific knowledge on the issue is lacking. In these cases, politicians use the precautionary principle, giving them the benefit of the doubt, using the aphorism: 'Absence of evidence is not evidence of absence'. This has been mentioned by a number of authors discussing the welfare of farmed invertebrates (Adamo, 2016; Birch, 2000; Elwood, 2011; Fischer, 2019; Knutsson and Munthe, 2017), although Birch (2017) introduces the concept of 'appropriate burden of proof for sentience', which may have not been attained for many orders of arthropods. Monsó (2018) argues that insect sentience may not matter that much. 
The first argument is that sentience of insects does secure them a right not to be raised and slaughtered for food. The second argument put forward is that pain in insects may be less severe or less harmful than that in vertebrates, which would favour consuming the first rather than the latter (for her numbers do not matter). The third argument is that a commitment not to harm other types of animals, such as mammals, may imply an obligation to consume insects. Meyers (2013) also mentioned that it is not only morally acceptable to eat insects but that it can be morally good to do so. This is because industrial farming of livestock is detrimental to livestock species while that of mini livestock is not, or much less so.

\section{Farmed insects and Brambell's five freedoms}

It we consider the five freedoms of Brambell (1965), we can make the following remarks about insect farming for food and feed.

\section{Freedom from hunger and thirst, by ready access to water and a diet to maintain health and vigour}

Ready access to fresh water and sufficient diet is normally provided, to get them into optimal shape and maintain their full health and vigour. The house fly will die of dehydration within days if water is not provided, and will cease reproducing if food of insufficient quality is provided (Erens et al., 2012). However, optimal production does not automatically mean species-appropriate conditions. For example, abiotic conditions (humidity, temperature, light) and biotic conditions (diet, crowding) may be modified to tailor the insect nutritional values to specific requirements of quantity and quality of the end product; these conditions may not be appropriate for the animal's well-being.

Starvation, i.e. one- or two-day fasting, is recommended to empty the insect gut before they are used as food or feed. Farmers want to sell insects, not the manure. This starvation should not be too long, as the animals may turn cannibalistic (for food safety reasons, starvation does not seem to be necessary (Wynants et al., 2017)). The question should also be asked, when rearing insects on cheap organic side streams, whether the development will not be too long such as with black soldier fly on manure (Oonincx et $a l ., 2015)$ and/or survival too low such as with crickets on municipal-scale food waste and diets composed largely of straw (Lundy et al., 2015).

\section{Freedom from discomfort, by providing an appropriate environment}

Insect housing must be such that it allows for speciesspecific movement needs, such as means of locomotion (crawling, walking, jumping, flying); social interaction (including cannibalism); reproduction; and concealment opportunities. Insects sometimes have specific pupation and egg-laying requirements, and food must not only have the right form and nutritional/other composition, but hygiene is also important (RDA, 2018). Live insects could be stored under cool conditions, and should be transported under appropriate abiotic conditions.

Normally, insect farming companies make sure that conditions for growth are optimal as this assures highest production, but as in livestock farming, crowding is an important issue. In insect farming, larvae (such as those of mealworms and the black soldier fly) are reared under crowded conditions, but often in higher densities than in a natural setting (Boppré and Vane-Wright, 2019). Mealworms produce metabolic heat and therefore the density (and with it the temperature) for optimal growth should not be too high or too low (Erens et al., 2012). A dilemma raised by Boppré and Vane-Wright (2019) is that the plasticity of living conditions in commercial mass rearing is lower for insects than for common production animals, meaning that appropriate (a)biotic conditions are more crucial for the survival of the animals.

\section{Freedom from pain, injury, or disease, by prevention or rapid diagnosis and treatment}

What companies fear most is disease, as this may compromise their whole enterprise (Eilenberg et al., 2017). To maintain a healthy stock, they will do their utmost by rearing insects under strict hygienic and optimal rearing conditions. The problem is that not much is known about pests and diseases when rearing insects. Veterinary science for insects is virtually absent, although there are now projects that are trying to mediate this (WUR, 2020).

As regards killing the insect, the main reason for choosing a particular killing method is often the quality of the product, e.g. for crickets the sensory qualities and physiochemical properties (Farina, 2017) and for the black soldier fly the lipid oxidation, colour and microbial load (Larouche et al., 2019). However, these reasons do not necessarily coincide with the well-being of the insect. Hakman et al. (2013) recommended in a report to the Dutch government that in insect-rearing either for food or feed, killing methods should be quick and effective. The methods proposed were freezing (insects are cold blooded), heating (cooking or blanching), and shredding. Most companies do not reveal how they kill their insects, but some take into account their cold bloodedness and cool them before shredding. Putting them in the fridge is often considered more 'humane' (putting them to sleep) than freezing them (they die) and therefore cooling may precede freezing (Bear, 2019). In addition to these killing methods, Zhen et al., (2020) used carbon dioxide and vacuum, and a method they called humane, i.e. carbon dioxide treatment followed by blanching. 
It has been suggested that because of the large numbers of small insects on insect farms, farmers would be emotionally and ethically detached when killing (Bear, 2019). It is true that for small animals in large numbers it is more likely that the group rather than the individual is taken into consideration.

\section{Freedom to express normal behaviour, by providing sufficient space, proper facilities, and appropriate company of the animal's own kind}

When comparing how insects live in nature and how they are reared, Boppré and Vane-Wright (2019) argue that on insect farms 'natural stresses' are eliminated as optimal (a)biotic conditions are offered. But the question is whether those benign conditions can be considered natural. Normally, an insect production facility has a reproduction unit, delivering the eggs or larvae for the production unit. In the production unit the animals are not allowed to reproduce as they themselves are the commercial product.

There may also be a question about the use of strains or mutants. There are several mutants of the housefly (Hoyer, 1966), one mutant being the curly winged fly (Nickel and Wagoner, 1975) used as feed for captive pets such as frogs and lizards. Curly refers to the deformed wings preventing the animal from being able to fly. The mutant is also blind so that enemies can no longer be seen. Curly winged flies are very active and only make small jumps. They do not hide, and they bump into everything, making them easy prey. Companies that sell them say that they are 'farm bred in ethical conditions'. The question is whether the rearing of these mutants can be considered ethical.

The industry also produces mealworms that are artificially treated with juvenile hormones. This influences the moulting of the larvae, which induces them to grow beyond their normal length. They are called 'Mighty mealies' and are used as pet food. Does this constitute normal behaviour for the animal, and should it be classified as unethical?

The rearing conditions of locusts in cages severely limits their ability to fly when they would normally migrate over hundreds of kilometres. The aggregated way of rearing will cause them to occur only in the gregarious form, as the solitary form requires the rearing of the insects individually. The rearing of locusts severely limits their normal behaviour.

\section{Freedom from fear and distress, by ensuring conditions and treatment that prevent mental suffering}

There has been a discussion about how difficult it is to measure fear, mental suffering, pain, and stress in invertebrates. If the precautionary principle is used, then we act as if they would be able to experience pain. Insects show stress responses that include the release of stress hormones/neurohormones (such as adipokinetic hormone) to maintain optimal immunity (Adamo 2012, 2017). Stressed animals, for example those that have received too little food, may become weak; this will lower their immune status and make them susceptible to opportunistic pathogens causing disease (Joosten et al., 2020). For example, stressed larvae of the super worm Zophobas morio are cannibalistic and rapidly spread the pathogen Pseudomonas aeruginosa (Maciel-Vergara et al., 2018). A higher incidence of the Acheta domesticus densovirus in the house cricket was observed under stress vectors such as crowding, waste accumulation, low protein diets, temperatures above $35^{\circ} \mathrm{C}$, and high relative humidity (Szelei et al., 2011).

\section{Guidelines for ethical behaviour}

In 2018 the Council of Animal Affairs of the Netherlands wrote a report entitled 'The emerging insect industry: invertebrates as production animals' (RDA, 2018). They recommended treating invertebrates as sentient beings, as future research may show that some species are indeed sentient. They considered investments in the welfare of invertebrates to be in the interests of the producer: 'To adapt farms to suit the needs and developmental stages of certain species as much as possible not only increases production, but is also important for the social acceptance of the insect industry.' The International Platform of Insects as Food and Feed, representing the interests of the insect production sector to EU policy-makers, states that all insect producers should adhere to high standards of animal welfare and ensure insect well-being (IPIFF, 2019).

Bear (2019) carried out a survey among insect farmers in the United Kingdom, mainly about killing insects. Farmers were concerned, not so much because they believe in the intrinsic value of insects, or that insects are 'sentient beings' or may experience pain, but more because of the way in which consumers may perceive this. However, all farmers were aware that they need to act in the face of scientific and ethical uncertainties. According to Bear (2019) further exploration of the understanding of 'good insect welfare' is necessary among farmers and their practices and actual or potential consumers.

Boppré and Vane-Wright (2019) propose creating an international Insect Welfare Charter - a framework that could be used to evaluate our current and future 'handling' of insects, based on species-appropriateness and respect towards all organisms while also considering environmental issues. 


\section{Conclusions}

The farming of insects as feed and food has been gaining momentum for the last ten years, exemplified by the increase in start-up companies and the number of scientific publications. This is because insects are increasingly being considered as a high-quality, efficient, and sustainable alternative protein source. Insect production has a lower environmental impact than the production of livestock and insects can bio-transform poor quality organic waste streams, contributing to a circular economy. However, the rapid increase in this newly emerging agricultural sector prompts questions about insect welfare and the ethics involved.

However, invertebrates do not enjoy a lot of empathy and this has to do with their negative reputation as being a nuisance (e.g. houseflies) and/or being dangerous (e.g. malaria mosquitoes). Then there is the anthropocentric attitude of human beings who consider themselves the most significant entity in the universe, while invertebrates are at the lower end of evolution. Grimaldi and Engel (2005) have put this in perspective in their book about the evolution of insects: 'People gladly imagine a life without insects. But if ants and termites alone were removed from the earth, terrestrial life would probably collapse.' They go on to mention the hazardous consequences for planet earth of removing these insect groups. Moreover, invertebrate brains seem to comprise more than $99 \%$ of the brains that exist on earth, which is one reason why invertebrate cognition and sentience deserve attention (Mikhalevich and Powell, 2020).

Baracchi et al. (2017) feel that caution is needed when dealing with interpretations of emotions in invertebrates as they are often anthropocentrically biased. Appropriate emotion-related terminology may be required through careful experiments objectively analysing invertebrate behaviour. The word 'anthropodenial' has been coined, which is a blindness to the human-like characteristics of animals or the animal-like characteristics of ourselves (Jones, 2020). Sneddon et al. (2018) suggest that there may be motivational issues involved: 'sentience is at the heart of the decision about whether to provide animals with legislative protection.' For fish, sentience was denied at first, but there now seems to be enough evidence to suggest that they can experience positive and negative emotions. If we have underestimated the moral value of vertebrates, Schukraft (2020) believes that we may have to redirect resources to invertebrates.

In general, the precautionary principle should be used, whereby we assume that invertebrates can experience emotions. This has consequences for the insect industry, which should take the necessary precautions so that insects are well treated. According to Browning and Veit (2020), granting invertebrates moral status does not imply that we must make large sacrifices on their behalf, although it is open to question where a threshold of 'too demanding' should be set. This applies to how they are raised as well as the way in which they are killed.

The industry for insects as food and feed is in its infancy and the related welfare issues are increasingly being highlighted. This may require an international effort to propose guidelines or standards of care to the industry for the well-being and slaughter of farmed invertebrates involving both the biological and social sciences. As almost all research published to date on the welfare perception of invertebrates concludes that too little is currently known, an increased research effort on the cognitive and emotional capacity of invertebrate species is required.

\section{Conflict of interest}

The author declares no conflict of interest.

\section{References}

Adámková, A., Adámek, M., Mlček, J., Borkovcová, M., Bednářová, M., Kouřimská, L. and Josef Skácel, E.V., 2017. Welfare of the mealworm (Tenebrio molitor) breeding with regard to nutrition value and food safety. Potravinarstvo Slovak Journal of Food Sciences 11: 460-465. https://doi.org/10.5219/779

Adamo, S., 2012. The effects of the stress response on immune function in invertebrates: an evolutionary perspective on an ancient connection. Hormones and Behavior 62: 324-330. https:// doi.org/10.1016/j.yhbeh.2012.02.012

Adamo, S.A., 2016. Do insects feel pain? A question at the intersection of animal behaviour, philosophy and robotics. Animal Behaviour 118: 75-79. https://doi.org/10.1016/j.anbehav.2016.05.005

Adamo, S.A., 2017. Stress responses sculpt the insect immune system, optimizing defense in an ever-changing world. Developmental \& Comparative Immunology 66: 24-32. https://doi.org/10.1016/j. dci.2016.06.005

Alexander, P., Brown, C., Arneth, A., Dias, C., Finnigan, J., Moran, D. and Rounsevell, M.D.A., 2017. Could consumption of insects, cultured meat or imitation meat reduce global agricultural land use? Global Food Security 15: 22-32. https://doi.org/10.1016/j. gfs.2017.04.001

Andrews, P.L.R., 2011. Laboratory invertebrates: only spineless, or spineless and painless? Institute for Laboratory Animal Research (ILAR) Journal 52: 121-125. https://doi.org/10.1093/ilar.52.2.121

Baracchi, D., Lihoreau, M. and Giurfa, M., 2017. Do insects have emotions? Some insights from bumble bees. Frontiers in Behavioral Neuroscience 11: 157-157. https://doi.org/10.3389/fnbeh.2017.00157

Barnhill, A. and Doggett, T., 2018. Food ethics I: food production and food justice. Philosophy Compass 13: e12479. https://doi. org/10.1111/phc3.12479

Barron, A.B. and Klein, C., 2016. What insects can tell us about the origins of consciousness. Proceedings of the National Academy of Sciences 113: 4900-4908. https://doi.org/10.1073/pnas.1520084113 
Bateson, P., 1991. Assessment of pain in animals. Animal Behaviour 42: 827-839. https://doi.org/10.1016/S0003-3472(05)80127-7

Bear, C., 2019. Approaching insect death: understandings and practices of the UK's edible insect farmers. Society \& Animals 27: 751-768. https://doi.org/10.1163/15685306-00001871

Bier, E., 2005. Drosophila, the golden bug, emerges as a tool for human genetics. Nature Reviews Genetics 6: 9-23. https://doi.org/10.1038/ nrg1503

Birch, J., 2017. Animal sentience and the precautionary principle. Animal Sentience 2: 17. Available at: https://tinyurl.com/y5dzyhd5.

Birch, J., 2020. The search for invertebrate consciousness. PhilSciArchive 16931. http://philsci-archive.pitt.edu/16931/

Boppré, M. and Vane-Wright, R.I., 2019. Welfare dilemmas created by keeping insects in captivity. In: Carere, C. and Mather, J. (eds) The welfare of invertebrate animals. Springer International Publishing, Cham, Switzerland, pp. 23-67. https://doi.org/10.1007/978-3-03013947-6_3

Bortolini, S., Macavei, L.I., Saadoun, J.H., Foca, G., Ulrici, A., Bernini, F., Malferrari, D., Setti, L., Ronga, D. and Maistrello, L., 2020. Hermetia illucens (L.) larvae as chicken manure management tool for circular economy. Journal of Cleaner Production 26: 121289. https://doi. org/10.1016/j.jclepro.2020.121289

Brambell, F.W.R., 1965. Report of the Technical Committee to enquire into the welfare of animals kept under intensive livestock husbandry systems. Command Papers 2836. Her Majesty's Stationery Office, London, UK.

Available at: https://tinyurl.com/y64m6ldx.

Browning, H. and Veit, W., 2020. Improving invertebrate welfare. Commentary on Mikhalevich \& Powell on invertebrate minds. Animal Sentience 5: 333. Available at: https://tinyurl.com/yxlls6ry.

Budelmann, B.U., 1995. The cephalopod nervous system: what evolution has made of the molluscan design. In: Breidbach, O. and Kutsch, W. (eds) The nervous systems of invertebrates: an evolutionary and comparative approach: with a Coda written by T.H. Bullock. Birkhäuser, Basel, Switzerland, pp. 115-138. https:// doi.org/10.1007/978-3-0348-9219-3_7

Burrell, B.D., 2017. Comparative biology of pain: what invertebrates can tell us about how nociception works. Journal of Neurophysiology 117: 1461-1473. https://doi.org/10.1152/jn.00600.2016

Cappellozza, S., Leonardi, G.M., Savoldelli, S., Carminati, D., Rizzolo, A., Cortellino, G., Terova, G., Moretto, E., Badaile, A., Concheri, G., Saviane, A., Bruno, D., Bonelli, M., Caccia, S., Casartelli, M. and Tettamanti, G., 2019. A first attempt to produce proteins from insects by means of a circular economy. Animals 9: 5. https://doi. org/10.3390/ani9050278

Carew, T.J. and Sahley, C.L., 1986. Invertebrate learning and memory: from behavior to molecules. Annual Review of Neuroscience 9: 435-487. https://doi.org/10.1146/annurev.ne.09.030186.002251

Coolen, I., Dangles, O. and Casas, J., 2005. Social learning in noncolonial insects? Current Biology 15: 1931-1935. https://doi. org/10.1016/j.cub.2005.09.015

Costanza, R., d'Arge, R., De Groot, R., Farber, S., Grasso, M., Hannon, B., Limburg, K., Naeem, S., O’Neill, R.V., Paruelo, J., Raskin, R.G., Sutton, P. and Van den Belt, M., 1997. The value of the world's ecosystem services and natural capital. Nature 387: 253-260. https:// doi.org/10.1038/387253a0
Drinkwater, E., Robinson, E.J.H. and Hart, A.G., 2019. Keeping invertebrate research ethical in a landscape of shifting public opinion. Methods in Ecology and Evolution 10: 1265-1273. https:// doi.org/10.1111/2041-210X.13208

Eilenberg, J., Jensen, A.B. and Hajek, A.E., 2017. Prevention and management of diseases in terrestrial invertebrates In: Hajek, A.E. and Shapiro-Ilan, D.I. (eds) Ecology of invertebrate diseases. John Wiley \& Sons, Ltd., Hoboken, NJ, USA, pp. 495-526. https://doi. org/10.1002/9781119256106.ch14

Eisemann, C.H., Jorgensen, W.K., Merritt, D.J., Rice, M.J., Cribb, B.W., Webb, P.D. and Zalucki, M.P., 1984. Do insects feel pain? - A biological view. Experientia 40: 164-167. https://doi.org/10.1007/ bf01963580

Elwood, R.W., 2011. Pain and suffering in invertebrates? ILAR Journal 52: 175-184.

Erens, J., Van Es, S., Haverkort, F., Kapsomenou, E. and Luijben, A., 2012. A bug's life: large-scale insect rearing in relation to animal welfare. Project 1052 'Large-scale insect rearing in relation to animal welfare', Wageningen University \& Research, Wageningen, the Netherlands.

Farina, M.F., 2017. How method of killing crickets impact the sensory qualities and physiochemical properties when prepared in a broth. International Journal of Gastronomy and Food Science 8: 19-23. http://dx.doi.org/10.1016/j.ijgfs.2017.02.002

Fischer, B., 2016. Bugging the strict vegan. Journal of Agricultural and Environmental Ethics 29: 255-263. https://doi.org/10.1007/ s10806-015-9599-y

Fischer, B., 2019. How to reply to some ethical objections to entomophagy. Annals of the Entomological Society of America 112: 511-517. https://doi.org/10.1093/aesa/saz011

Food and Agriculture Organization of the United Nations (FAO), 2014. Mitigation of food wastage. Societal costs and benefits. FAO, Rome, Italy. Available at: http://www.fao.org/3/a-i3989e.pdf.

Giurfa, M., 2013. Cognition with few neurons: higher-order learning in insects. Trends in Neurosciences 36: 285-294. https://doi. org/10.1016/j.tins.2012.12.011

Gjerris, M., Gamborg, C. and Rocklinsberg, H., 2015. Entomophagy - why should it bug you? The ethics of insect production for food and feed In: Dumitras, D.E., Jitea, I.M. and Aerts, S. (eds) Know your food: food ethics and innovation. Wageningen Academic Publishers, Wageningen, the Netherlands, pp. 345-352. https:// doi.org/10.3920/978-90-8686-813-1_52

Gossard, H.A., 1909. Relation of insects to human welfare. Journal of Economic Entomology 2: 313-332.

Grimaldi, D. and Engel, M.S., 2005. Evolution of the insects. Cambridge University Press, New York, NY, USA.

Guo, J. and Guo, A., 2005. Crossmodal interactions between olfactory and visual learning in Drosophila. Science 309: 307-310. https:// doi.org/10.1126/science.1111280

Hakman, A., Peters, M. and Van Huis, 2013. Toelatingsprocedure voor insecten als mini-vee voor het plaatsen van nieuwe insectensoorten op de lijst voor productie te houden dieren. Wageningen University, Wageningen, the Netherlands. 
Hallmann, C.A., Sorg, M., Jongejans, E., Siepel, H., Hofland, N., Schwan, H., Stenmans, W., Müller, A., Sumser, H., Hörren, T., Goulson, D. and De Kroon, H., 2017. More than 75 percent decline over 27 years in total flying insect biomass in protected areas. PLoS ONE 12: e0185809. https://doi.org/10.1371/journal.pone.0185809

Heckmann, L.H., Andersen, J.L., Eilenberg, J., Fynbo, J., Miklos, R., Jensen, A.N., Nørgaard, J.V. and Roos, N., 2019. A case report on inVALUABLE: insect value chain in a circular bioeconomy. Journal of Insects as Food and Feed 5: 9-13. https://doi.org/10.3920/ JIFF2018.0009

Hedwig, B., 2014. Insect hearing and acoustic communication. Springer, Heidelberg, Germany.

Herculano-Houzel, S., 2009. The human brain in numbers: a linearly scaled-up primate brain. Frontiers in Human Neuroscience 3: 31. https://doi.org/10.3389/neuro.09.031.2009

Herculano-Houzel, S., Mota, B. and Lent, R., 2006. Cellular scaling rules for rodent brains. Proceedings of the National Academy of Sciences 103: 12138. https://doi.org/10.1073/pnas.0604911103

Horvath, K., Angeletti, D., Nascetti, G. and Carere, C., 2013. Invertebrate welfare: an overlooked issue. Annali dell'Istituto Superiore di Sanità 49: 9-17. https://doi.org/10.4415/ANN_13_01_04

Hoyer, R.F., 1966. Some new mutants of the house fly, Musca domestica, with notations of related phenomena. Journal of Economic Entomology 59: 133-137. https://doi.org/10.1093/jee/59.1.133

Hwang, R.Y., Zhong, L., Xu, Y., Johnson, T., Zhang, F., Deisseroth, K. and Tracey, W.D., 2007. Nociceptive neurons protect Drosophila larvae from parasitoid wasps. Current Biology 17: 2105-2116. https://doi.org/10.1016/j.cub.2007.11.029

Im, S.H. and Galko, M.J., 2012. Pokes, sunburn, and hot sauce: Drosophila as an emerging model for the biology of nociception. Developmental Dynamics 241: 16-26. https://doi.org/10.1002/ dvdy. 22737

Intergovernmental Science-Policy Platform on Biodiversity and Ecosystem Services (IPBES), 2019. Report of the Plenary of the Intergovernmental Science-Policy Platform on Biodiversity and Ecosystem Services on the work of its seventh session. IPBES, Bonn, Germany. Available at: https://ipbes.net/sites/default/files/ ipbes_7_10_add.1_en_1.pdf.

International Platform of Insects for Food and Feed (IPIFF), 2019. Ensuring high standards of animal welfare in insect production. IPIFF, Brussels, Belgium. Available at: https://tinyurl.com/yd88udze

Jena, N.P., 2017. Animal welfare and animal rights: an examination of some ethical problems. Journal of Academic Ethics 15: 377-395. https://doi.org/10.1007/s10805-017-9282-1

Jones, R.C., 2020. Speciesism and human supremacy in animal neuroscience. In: Johnson, L., Fenton A. and Shriver A. (eds) Neuroethics and nonhuman animals. Advances in Neuroethics. Springer, Cham, Switzerland, pp. 99-115. https://doi. org/10.1007/978-3-030-31011-0_6

Joosten, L., Lecocq, A., Jensen, A.B., Haenen, O., Schmitt, E. and Eilenberg, J., 2020. Review of insect pathogen risks for the black soldier fly (Hermetia illucens) and guidelines for reliable production. Entomologia Experimentalis et Applicata 168: 432-447. https://doi. org/10.1111/eea.12916
Karam, C.S., Jones, S.K. and Javitch, J.A., 2019. Come fly with me: an overview of dopamine receptors in Drosophila melanogaster. Basic \& Clinical Pharmacology \& Toxicology 126: 56-65. https:// doi.org/10.1111/bcpt.13277

Klein, C. and Barron, A.B., 2016. Insects have the capacity for subjective experience. Animal Sentience 1: 100.

Knutsson, S., 2016. Reducing suffering among invertebrates such as insects. Sentience Politics 1: 1-18. Available at: https://ea-foundation. org/files/reducing-suffering-invertebrates.pdf.

Knutsson, S. and Munthe, C., 2017. A virtue of precaution regarding the moral status of animals with uncertain sentience. Journal of Agricultural and Environmental Ethics 30: 213-224. https://doi. org/10.1007/s10806-017-9662-y

Larouche, J., Deschamps, M.-H., Saucier, L., Lebeuf, Y., Doyen, A. and Vandenberg, G.W., 2019. Effects of killing methods on lipid oxidation, colour and microbial load of black soldier fly (Hermetia illucens) larvae. Animals 9: 182. https://doi.org/10.3390/ani9040182 Le Neindre, P., Bernard, E., Boissy, A., Boivin, X., Calandreau, L., Delon, N., Deputte, B., Desmoulin-Canselier, S., Dunier, M., Faivre, N., Giurfa, M., Guichet, J.-L., Lansade, L., Larrère, R., Mormède, P., Prunet, P., Schaal, B., Servière, J. and Terlouw, C., 2017. Animal consciousness. EFSA Supporting Publications 14: 1196E. https:// doi.org/10.2903/sp.efsa.2017.EN-1196

Leadbeater, E. and Chittka, L., 2007. Social learning in insects - from miniature brains to consensus building. Current Biology 17: 703713. https://doi.org/10.1016/j.cub.2007.06.012

Lestel, D. and Taylor, H., 2013. Shared life: an introduction. Social Science Information 52: 183-186. https://doi. org/10.1177/0539018413477335

Lockwood, J.A., 1987. The moral standing of insects and the ethics of extinction. Florida Entomologist 70: 70-89. https://www.jstor. org/stable/3495093

Looy, H., Dunkel, F.V. and Wood, J.R., 2014. How then shall we eat? Insect-eating attitudes and sustainable foodways. Agriculture and Human Values 31: 131-141. https://doi.org/10.1007/s10460-0139450-x

Lundy, M.E. and Parrella, M.P., 2015. Crickets are not a free lunch: protein capture from scalable organic side-streams via high-density populations of Acheta domesticus. PLoS ONE 10: e0118785. https:// doi.org/10.1371/journal.pone.0118785

Maciel-Vergara, G., Jensen, A. and Eilenberg, J., 2018. Cannibalism as a possible entry route for opportunistic pathogenic bacteria to insect hosts, exemplified by Pseudomonas aeruginosa, a pathogen of the giant mealworm Zophobas morio. Insects 9: 88. https://doi. org/10.3390/insects 9030088

Mason, G.J., 2011. Invertebrate welfare: where is the real evidence for conscious affective states? Trends in Ecology \& Evolution 26: 212-213. https://doi.org/10.1016/j.tree.2011.02.009

Mather, J.A., 2011. Philosophical background of attitudes toward and treatment of invertebrates. Institute for Laboratory Animal Research (ILAR) Journal 52: 205-212.

Mather, J.A. and Carere, C., 2019. Consider the individual: personality and welfare in invertebrates. In: Carere, C. and Mather, J. (eds) The welfare of invertebrate animals. Springer International Publishing, Cham, Switzerland, pp. 229-245. https://doi.org/10.1007/978-3030-13947-6_10 
McClements, D.J., 2019. Towards a more ethical and sustainable edible future: one burger at a time. In: McClements, D.J. (ed.) Future foods: how modern science is transforming the way we eat. Springer International Publishing, Cham, Switzerland, pp. 323-361. https:// doi.org/10.1007/978-3-030-12995-8_11

McEachern, M.G., 2018. Ethical food: transitioning towards sustainable meat consumption? Journal of Consumer Ethics 2: 26-32. Available at: https://tinyurl.com/yy7ad7jf.

Mendl, M., Paul, Elizabeth S. and Chittka, L., 2011. Animal behaviour: emotion in invertebrates? Current Biology 21: 463-465. https://doi. org/10.1016/j.cub.2011.05.028

Mendl, M.T. and Paul, E.S., 2016. Bee happy. Science 353: 1499-1500. https://doi.org/10.1126/science.aai9375

Menzel, R. and Giurfa, M., 2001. Cognitive architecture of a mini-brain: the honeybee. Trends in Cognitive Sciences 5: 62-71. https://doi. org/10.1016/S1364-6613(00)01601-6

Merker, B., 2016. Insects join the consciousness fray. Animal Sentience 1: 109. Available at: https://tinyurl.com/y5hm6grb.

Meyer-Rochow, V. and Kejonen, 2020. Could Western attitudes towards edible insects possibly be influenced by idioms containing unfavourable references to insects, spiders and other invertebrates? Foods 9: 172. https://doi.org/10.3390/foods9020172

Meyers, C.D., 2013. Why it is morally good to eat (certain kinds of) meat: the case for entomophagy. Southwest Philosophy Review 29: 119-126.

Mikhalevich, I. and Powell, R., 2020. Minds without spines: evolutionarily inclusive animal ethics. Animal Sentience 5: 329. Available at: https://tinyurl.com/y3ysge64.

Moltschaniwskyj, N.A., Hall, K., Lipinski, M.R., Marian, J.E.A.R., Nishiguchi, M., Sakai, M., Shulman, D.J., Sinclair, B., Sinn, D.L., Staudinger, M., Van Gelderen, R., Villanueva, R. and Warnke, K., 2007. Ethical and welfare considerations when using cephalopods as experimental animals. Reviews in Fish Biology and Fisheries 17: 455-476. https://doi.org/10.1007/s11160-007-9056-8

Monsó, S., 2018. Why insect sentience might not matter very much. In: Springer, S. and Grimm, H. (eds) Professionals in food chains. Wageningen Academic Publishers, Wageningen, the Netherlands, pp. 375-380. https://doi.org/10.3920/978-90-8686-869-8_59

Mora, C., D.P. Tittensor, S. Adl, A.G.B. Simpson, and B. Worm, 2011. How many species are there on earth and in the ocean? PLOS Biology 9: e1001127. https://doi.org/10.1371/journal.pbio.1001127

Nava, A.L., Higareda, T.E., Barreto, C., Rodríguez, R., Márquez, I. and Palacios, M.L., 2020. Circular economy approach for mealworm industrial production for human consumption. IOP Conference Series: Earth and Environmental Science 463: 012087. https://doi. org/10.1088/1755-1315/463/1/012087

Nickel, C.A. and Wagoner, D.E., 1975. Mutants on linkage groups 3 and 4 of the house fly. Annals of the Entomological Society of America 67: 775-776.

Nordgren, A., 2012. Ethical issues in mitigation of climate change: the option of reduced meat production and consumption. Journal of Agricultural and Environmental Ethics 25: 563-584. https://doi. org/10.1007/s10806-011-9335-1
Oonincx, D.G.A.B., Van Huis, A. and Van Loon, J.J.A., 2015. Nutrient utilisation by black soldier flies fed with chicken, pig, or cow manure. Journal of Insects as Food and Feed 1: 131-139. https:// doi.org/10.3920/JIFF2014.0023

Pali-Schöll, I., Binder, R., Moens, Y., Polesny, F. and Monsó, S., 2018. Edible insects - defining knowledge gaps in biological and ethical considerations of entomophagy. Critical Reviews in Food Science and Nutrition 59: 2760-2761. https://doi.org/10.1080/10408398. 2018.1468731

Paul, E.S. and Mendl, M.T., 2016. If insects have phenomenal consciousness, could they suffer? Animal Sentience 1: 128. Available at: https://tinyurl.com/y2aknsd8.

Perry, C.J., Baciadonna, L. and Chittka, L., 2016. Unexpected rewards induce dopamine-dependent positive emotion-like state changes in bumblebees. Science 353: 1529. https://doi.org/10.1126/science. aaf 4454

Pollo, S. and Vitale, A., 2019. Invertebrates and humans: science, ethics, and policy. In: Carere, C. and Mather J. (eds.) The Welfare of Invertebrate Animals. Springer International Publishing, Cham, pp. 7-22. https://doi.org/10.1007/978-3-030-13947-6_2

Prat, Y., 2019. Animals have no language, and humans are animals too. Perspectives on Psychological Science 14: 885-893. https:// doi.org/10.1177/1745691619858402

Raad voor Dieraangelegenheden (RDA), 2018. The emerging insect industry: invertebrates as production animals. Council on Animal Affairs in the Netherlands, The Hague, the Netherlands. Available at: https://english.rda.nl/publications/publications/2018/09/03/ the-emerging-insect-industry

Roitberg, B., 2018. Chemical communication. In: Córdoba-Aguilar, A., González-Tokman, D. and González-Santoyo, I. (eds.) Insect behavior: from mechanisms to ecological and evolutionary consequences, pp. 145-157. Oxford University Press, Oxford.

Scherer, L., Tomasik, B., Rueda, O. and Pfister, S., 2017. Framework for integrating animal welfare into life cycle sustainability assessment. The International Journal of Life Cycle Assessment 23: 1476-1490. https://doi.org/10.1007/s11367-017-1420-x

Schukraft, J., 2020. Comparisons of capacity for welfare and moral status across species. Effective Altruism Forum. Available at: https://forum.effectivealtruism.org/posts/EDCwbDEhwRGZjqY6S/ invertebrate-welfare-cause-profile.

Sherwin, C.M., 2001. Can invertebrates suffer? Or, how robust is argument-by-analogy? Animal Welfare 10: 103-118.

Shih, J., Hodge, R. and Andrade-Navarro, M.A., 2015. Comparison of inter- and intraspecies variation in humans and fruit flies. Genomics Data 3: 49-54. https://doi.org/10.1016/j.gdata.2014.11.010

Smetana, S., 2020. Life cycle assessment of specific organic waste-based bioeconomy approaches. Current Opinion in Green and Sustainable Chemistry 23: 50-54. https://doi.org/10.1016/j.cogsc.2020.02.009

Smetana, S., Mathys, A., Knoch, A. and Heinz, V., 2015. Meat alternatives: life cycle assessment of most known meat substitutes. The International Journal of Life Cycle Assessment 20: 1254-1267. https://doi.org/10.1007/s11367-015-0931-6

Smyth, D., 1978. Alternatives to Animal Experiments.Solar Press, London, UK. 
Sneddon, L.U., Elwood, R.W., Adamo, S.A. and Leach, M.C., 2014. Defining and assessing animal pain. Animal Behaviour 97: 201-212. https://doi.org/10.1016/j.anbehav.2014.09.007

Sneddon, L.U., Lopez-Luna, J., Wolfenden, D.C.C., Leach, M.C., Valentim, A.M., Steenbergen, P.J., Bardine, N., Currie, A.D., D.M., B. and Brown, C., 2018. Fish sentience-denial: muddying the waters. Animal Sentience 3: 21. Available at: https://tinyurl.com/y28rugto. Stork, N.E., 2018. How many species of insects and other terrestrial arthropods are there on earth? Annual Review of Entomology 63: 31-45. https://doi.org/10.1146/annurev-ento-020117-043348

Szelei, J., Woodring, J., Goettel, M.S., Duke, G., Jousset, F.X., Liu, K.Y., Zadori, Z., Li, Y., Styer, E., Boucias, D.G., Kleespies, R.G., Bergoin, M. and Tijssen, P., 2011. Susceptibility of North-American and European crickets to Acheta domesticus densovirus (AdDNV) and associated epizootics. Journal of Invertebrate Pathology 106: 394-399. https://doi.org/10.1016/j.jip.2010.12.009

Tapanen, T., 2018. Environmental potential of insects as food protein source. Master's Thesis, LUT University, School of Energy Systems, Sustainability Science and Solutions, Lappeenranta, Finland.

Tarsitano, M., 2006. Route selection by a jumping spider (Portia labiata) during the locomotory phase of a detour. Animal Behaviour 72: 1437-1442. https://doi.org/10.1016/j.anbehav.2006.05.007

Tomasik, B., 2019. Do smaller animals have faster subjective experiences? Available at: https://reducing-suffering.org/smallanimals-clock-speed/.

Tracey, W.D., Jr., Wilson, R.I., Laurent, G. and Benzer, S., 2003. Painless, a Drosophila gene essential for nociception. Cell 113: 261-273. https://doi.org/10.1016/s0092-8674(03)00272-1

Van Huis, A., 2014. The global impact of insects. Farewell address upon retiring as Professor of Tropical Entomology at Wageningen University on 20 November 2014. Available at: https://edepot. wur.nl/410394.

Van Huis, A., 2019. Environmental sustainability of insects as human food. Elsevier Reference Collection in Food Science, pp. 1-5. https:// doi.org/10.1016/B978-0-08-100596-5.22589-4

Van Huis, A., 2020. Insects as food and feed, a new emerging agricultural sector: a review. Journal of Insects as Food and Feed 6: 27-44. https://doi.org/10.3920/JIFF2019.0017
Van Huis, A. and Oonincx, D.G.A.B., 2017. The environmental sustainability of insects as food and feed. A review. Agronomy for Sustainable Development 37: 43. https://doi.org/10.1007/s13593017-0452-8

Van Klink, R., Bowler, D.E., Gongalsky, K.B., Swengel, A.B., Gentile, A. and Chase, J.M., 2020. Meta-analysis reveals declines in terrestrial but increases in freshwater insect abundances. Science 368: 417. https://doi.org/10.1126/science.aax9931

Walters, E., Illich, P., Weeks, J. and Lewin, M., 2001. Defensive responses of larval Manduca sexta and their sensitization by noxious stimuli in the laboratory and field. Journal of Experimental Biology 204: 457-469.

Waltner-Toews, D. and Houle, K., 2017. Biophilia on the dinner plate: a conversation about ethics and entomophagy. Food Ethics 1: 157171. https://doi.org/10.1007/s41055-017-0015-3

Wilson, E.O., 1987. The little things that run the world (the importance and conservation of invertebrates). Conservation Biology 1: 344-346.

Wilson-Sanders, S.E., 2011. Invertebrate models for biomedical research, testing, and education. ILAR Journal 52: 126-152. https:// doi.org/10.1093/ilar.52.2.126

Wageningen University \& Research (WUR), 2020. Insect doctors. WUR, Wageningen, the Netherlands. Available at: https://www. wur.nl/en/newsarticle/INSECT-DOCTORS-1.htm.

Wynants, E., Crauwels, S., Lievens, B., Luca, S., Claes, J., Borremans, A., Bruyninckx, L. and Van Campenhout, L., 2017. Effect of postharvest starvation and rinsing on the microbial numbers and the bacterial community composition of mealworm larvae (Tenebrio molitor). Innovative Food Science \& Emerging Technologies 42: 8-15. https://doi.org/10.1016/j.ifset.2017.06.004

Yack, J.S., 2016. Vibrational signaling. In: Pollack, G., Mason, A., Popper, A. and Fay, R. (eds) Insect hearing. Springer handbook of auditory research, vol 55. Springer, Cham, Switzerland, pp. 99-123. https://doi.org/10.1007/978-3-319-28890-1_5

Zhen, Y., Chundang, P., Zhang, Y., Wang, M., Vongsangnak, W., Pruksakorn, C. and Kovitvadhi, A., 2020. Impacts of killing process on the nutrient content, product stability and in vitro digestibility of black soldier fly (Hermetia illucens) larvae meals. Applied Siences 10(17): 6099. https://doi.org/10.3390/app10176099 